\title{
Christian Bromberger, Azadeh Kian (dir.). De l'Iran au Jazz, à cheval. Mélanges en hommage à Jean-Pierre Digard
}

\section{Rémy Boucharlat}

\section{(2) OpenEdition Journals}

Édition électronique

URL : http://journals.openedition.org/abstractairanica/47103

DOI : 10.4000/abstractairanica.47103

ISBN : 1961-960X

ISSN : 1961-960X

Éditeur :

CNRS (UMR 7528 Mondes iraniens et indiens), Éditions de l'IFRI

\section{Référence électronique}

Rémy Boucharlat, « Christian Bromberger, Azadeh Kian (dir.). De I'Iran au Jazz, à cheval. Mélanges en hommage à Jean-Pierre Digard », Abstracta Iranica [En ligne], Volume 37-38-39 | 2018, document 7, mis en ligne le 30 décembre 2018, consulté le 26 septembre 2020. URL : http://journals.openedition.org/ abstractairanica/47103 ; DOI : https://doi.org/10.4000/abstractairanica.47103

Ce document a été généré automatiquement le 26 septembre 2020.

Tous droits réservés 


\title{
Christian Bromberger, Azadeh Kian (dir.). De l'Iran au Jazz, à cheval. Mélanges en hommage à Jean-Pierre Digard
}

\author{
Rémy Boucharlat
}

\section{RÉFÉRENCE}

Christian Bromberger, Azadeh Kian (dir.). De l'Iran au Jazz, à cheval. Mélanges en hommage à Jean-Pierre Digard. Paris : CNRS Éditions, 2015, 272 p., ill., ISBN : 978-2-271-08306-7

1 Le titre de ce livre éclaire quelques-unes des passions scientifiques et personnelles de Jean-Pierre Digard, même si celui-ci est avant tout un ethnologue. Des collègues et élèves, mais tous des amis, ont voulu exprimer en une trop courte journée de réunion leur estime à celui qui est connu dans le monde académique pour ses travaux sur les nomades Bakhtyāri et plus généralement sur les nomades, et sur les animaux domestiques, tout d'abord le cheval, une de ses passions.

2 La première partie, "Jean-Pierre Digard entre jazz, science et éthique », évoque quelques facettes de l'homme. Pour les deux autres parties, signalons seulement les contributions se rapportant au monde iranien. Dans la deuxième partie, « Du pastoralisme nomade au statut de l'animal ", sept articles traitent du nomadisme ou des "éleveurs mobiles", et pour l'Iran, Yann Richard, «C. J. Edmonds et les tribus d'Iran ", Richard Tapper, "Pastoralism and patriliny ", Mohammad Hossein PapoliYazdi, «L'expulsion des semi-nomades des forêts du nord de l'Iran ». L'intermède de Soheila Shahshahani « Birds, Love and Liberation in Tehran 2012 », traite de la relation entre les hommes et les oiseaux. Les trois contributions de la troisième partie, «L'Iran, du chiisme à la République islamique, concernent l'Iran : Anne-Sophie Vivier Muresan, «Les imams dans le chiisme populaire ; Bernard Hourcade, «Les citadins ont-ils effacé 
les diversités ethniques?; Faribah Adelkhah, "Iran : une République si mobile et si contrôlée, ou quand le naturel revient au galop... ». L'ensemble du volume a fait l'objet d'un compte-rendu détaillé dans Studia Iranica 45, 2 (2016).

\section{AUTEURS}

\section{RÉMY BOUCHARLAT}

UMR 5133 CNRS-Université de Lyon 